\title{
The Perception of International Students on the Facility and Sport Tourism Event Management
}

\author{
Japhet Ndayisenga ${ }^{1}$ and Tomoliyus ${ }^{1}$ \\ ${ }^{1}$ Yogyakarta State University, Faculty of Sport Sciences, Yogyakarta, Indonesia
}

\begin{abstract}
The new challenges facing event sport tourism are explored in two parts: from an economic perspective, and social field as the tool to improve decision-making processes when organising sport events. The aim of this paper is to develop a deeper understanding of the perception from customers on the facility of sport tourism event management in other to allow continuance business. This study was a descriptive research with mixed methods. The subjects of this research were 51 international students from in 45 countries taken by representative random sampling. Data analysis techniques using correlation and linear regression among indicators-variables, and between variables themselves with Software SPSS.21 and PLS-SEM. The results showed that there was a significant effect from environment of the tourism place to the tourists'satisfaction, the relationship between satisfaction-perception was largely weak because of the transaction fees which are not moderated, and the deep lacking of types of sports in the Malang tourism place. Thus suitable environment, types of sports, tariff moderated become strong management tools that help sports managers to decide how to allocate resources to improve satisfaction, customer loyalty Originality/value: This study is the first to apply to explain career to the current situation in Malang tourism place.
\end{abstract}

Key words: perception, facility, sport tourism event management

\section{Introduction}

Tourism plays an important role in accelerating economic growth and is currently one of the largest industries in the world (Mhanna, 2018). One of the fastest growing travels is tourism related to sports or exercise, where sport tourism is one of the most extensively studied (Gibson, Lamont, Kennelly, \& Buning, 2018). Infrastructure, environments and facilities at various locations tourism have become very interesting (Buning, 2018). Sport event tourism has become an activity that enhances the potential of cities or countries to compete in this globalized world (Allen, Drane, Byon, \& Mohn, 2010). It is also important to know that tourists are interested in sport tend to spend more, stay longer duration and stimulating the tourism sector so as well. The tourism industry plays an important role in the economies of all countries in the world, as it can generate substantial income for the nation and create jobs for the entire population. It is also an industry that contributes to other businesses, which contributes to investment, employment, and distribution of income to the local community (Homafar, Honari, \& Heidary, 2011).

Tourism industry has started to recognize sport tourism, i.e. the experience of travel to engage in or view sport-related activities as an important market. In order to compete in the growing sport tourism market, it is crucial for communities to develop a profound understanding of the benefits and impacts of sport tourism, of the process of bidding for events, possible sponsorship opportunities and other elements involved in the planning and hosting of a successful sport event. Sport tourism refers to the experience of travel to engage in or view sport-related activities. It is generally recognized that there are three types of sport tourism: Sport event tourism, active sport tourism, and nostalgia sport tourism. Sports event tourism includes hallmark events such as

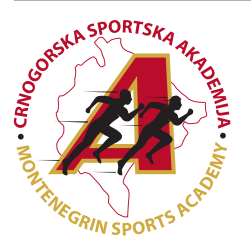

Correspondence:

Tomoliyus

Yogyakarta State University, Faculty of Sport Sciences, Yogyakarta, Indonesia

E-mail: tomoliyus@uny.ac.id 
the Olympic Games and the World Cup, football is part of this type of sport tourism. Nostalgia sport tourism involves traveling to famous sport-related attractions. Visits to various Sporting hall of fames such as the Women's College Basketball Hall of Fame in Knoxville, Tennessee and the Baseball Hall of Fame in Cooperstown (Shin, Chiu, \& Lee, 2018).

Tourism organisations strongly depend on the strategically right employment who could take information from customers, and become the strong tool for manage the business. This research was very important because the results showed the strong and weak points belong to Malang tourism place, so it will be an opportunity to improve it. Finally the information from this study was to help Malang tourism place to prepare for the competition and maintain the customers, not only Malang tourism but for all business owners such as development guidelines.

Sports tourism is the act of traveling from one location to another with the goal of being an audience member to a sports recreation, competition of any kind (Van Rheenen, Cernaianu, \& Sobry, 2016). While different sports have different sports tourism consumers, all sports have taken a popularity increase in recent years, sports tourism has gained popularity in recent years, The types of sports tourism consumers vary from sport to sport. one must stop and consider what it really is and why it has become so popular among the sports fan crowds. The more you learn about whom sport-tourists are, where they are coming from and their motives and expectations for their visit, the better one can plan events and services (Osman, Cole, \& Vessell, 2006).

Intensive market analysis and research into people's tastes, preferences and attitudes are now the backbone of market planning. Market research is the tool for listening to customers. Before organizations can offer new events, they must understand what sport-tourists need, how they think, and what their questions are. Much of the marketing research process therefore aims to get close to the customer, there by permitting the organization to understand the customer's perspective and needs (Higham, 1999). Why is it important to gather information about sport tourists. The marketing concept asserts that the key to achieving organizational goals consists in determining the needs and wants of target markets and delivering the desired satisfaction more effectively and more efficiently than competitors (Mousavi Gilani, \& Sajadi, 2013).

\section{Methods}

This is the descriptive research with mixed method qualitati- ve and quantitative approaches. The population in this study was 51 international students representatives from in 45 different countries, who study in Indonesia. The study sample was determined by representative sampling. Data collection techniques used questionnaires. Data analysis techniques using PLS - SEM and SPSS. The research hope was to show the actual situation in tourism place of Malang through the below Indicators and variables: (1) Streets, (2) Hygiene, (3) Toilet, (4) Places, (5) Equipment the later are indicators for the Environment variable, however the facility, (6) was an indicator of Variable customer satisfaction at the tourism place, (7) Rafting, (8) River, and types of sports were indicators of event sport dependent variable, (8) Ticket or price were indicators of transactions fees dependent variable also, in add more Attitude was the perception indicator. Secondly the all variable (dependent and independent) were the following below:

a) Environment variable (X1): dependent variable

b) Transaction fees variable (X2): dependent variable

c) Variable customer satisfaction at Fitness (Y1): independent variable

d) Perception customer on the tourism event (Y2): independent variable

The research model and hypothesis in this study can be described and explained:

\section{Research Hypothesis}

1. There is correlation between indicators and Variable.

2. There is correlation between dependent variable and independent variable.

3. There is linear regression between dependent variable and independent variable

\section{The Research Structural Equation Modeling}

The Diagram 1. below will help us to find the correlation that will exist between the indicators and the variables, and secondly the correlation that will exist between the variables themselves as the research hypotheses demonstrated above.

This research structural equation modeling has five variables and eleven indicators, 5 indicators (street, toilet, hygiene, equipment, and places) for the environment variable; 3 indicators (rafting, river, and kind of sport) for event sport dependent variable; one indicator attitude perception independent variable; one indicator facility for satisfaction independent, and one indicator ticket or price for transaction fees dependent variable all will be showed on the Diagram 1. below.

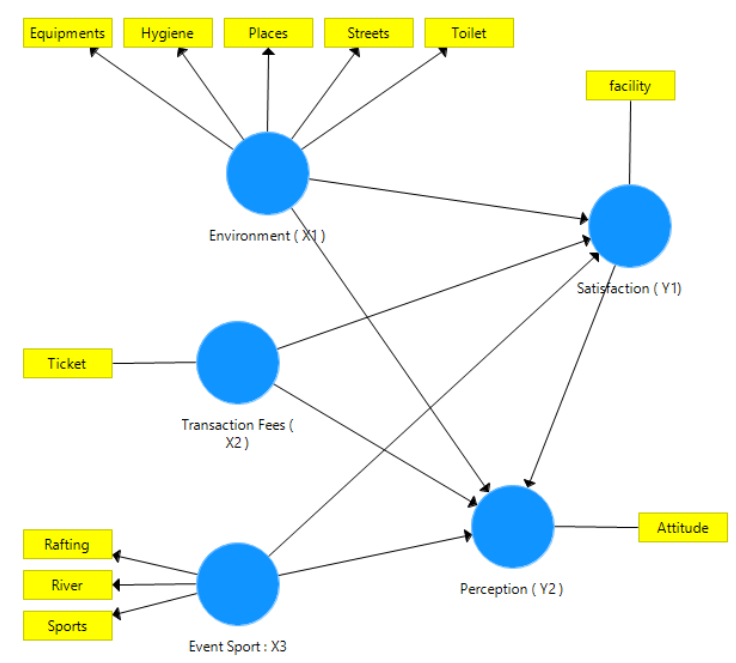

Diagram 1. The Research Structural Equation Modeling 


\section{Results}

The result from this research has been presented and explanned such us: In the Table 1. latent Variables Cronbach's Alpha rho-A Composite Reliability CR Average Variance Extracted (AVE). Reliability of internal consistency is assessed by evaluating of the combination reliability of all constructions. In our study, all composite reliability values were well above the 0.70 , excpet to the environment dependent variable where Cronbach's Alpha rho-A, and Average Variance are less than the significant values, this one is explained by the strong weack of the conditon of the toilet in the tourism place which need to be improve more than others indicators, and variable. Secondly the event sports also Cronbach's Alpha rho-A, Average Variance Extracted (AVE) were strongly weack because of the strong lacking of the types of sports in this tourism place, for others threshold, indicating that the combined reliability of each reflective latent variable was acceptable and confirmed construct reliability (Hiba \& Faisal, 2018).

Table 1. Internal consistency reliability (CR) and convergent validity (AVE)

\begin{tabular}{ccccc}
\hline Matrix & \multicolumn{4}{c}{ Construct Reliability and Validity } \\
& $\begin{array}{c}\text { Cronbach's } \\
\text { Alpha }\end{array}$ & Rho_A & $\begin{array}{c}\text { Composite } \\
\text { Reliability }\end{array}$ & $\begin{array}{c}\text { Average Variance } \\
\text { Extracted }\end{array}$ \\
\hline Environment: (X1) & 0.699 & 0.721 & 0.802 & 0.455 \\
Event Sport: (X3) & 0.260 & 0.682 & 0.699 & 0.550 \\
Perception: (Y2) & 1.000 & 1.000 & 1.000 & 1.000 \\
Satisfaction: (Y1) & 1.000 & 1.000 & 1.000 & 1.000 \\
Transaction fees & 1.000 & 1.000 & 1.000 & 1.000 \\
\hline
\end{tabular}

Construct validity is the extent to which items measure (Hiba \& Faisal, 2018). To test construct validity, we tested convergent validity and discriminant validity. Convergent validity is the extent to which an AVE measure reflects the average communality for each latent factor factor (Nimon, 2012), and must be 0.50 or higher (Hiba \& Faisal, 2018). In our study, all AVE values above 0.50, expet one factor or indicator belonging to the environment variable as it has been explained above. The dimensions showed that convergent validity of each latent factor is acceptable (Table 1).

To assess collinearity, we consider the variance inflation factor (VIF). As can be concluded from Table 2., the VIF values in our study are well below the threshold value of 0.50 , indicating that collinearity is not a problem (Hiba \& Faisal, 2018).

\begin{tabular}{lc} 
Table 2. Collinearity Assessment (VIF) \\
\hline Collinearity & Statistics (VIF) \\
\hline Attitude & 1.000 \\
Equipment & 1.325 \\
Hygiene & 1.297 \\
Places & 1.591 \\
Rafting & 1.975 \\
River & 2.034 \\
Sports & 1.056 \\
Streets & 1.557 \\
Ticket & 1.000 \\
Toilet & 1.235 \\
Facility & 1.000
\end{tabular}

The Diagram 2. below describes the relationship or correlation between indicators and variables, is there any influence from the indicator on the variable or the influence between variables themselves. The outcome of the research focused on the type of correlation like: a strong positive correlation from 1 to $(0.5)$ and a strong negative correlation from -1 to $(-0.5)$ while the weak correlation is positive from between 0.5 to 0.00 and a weak negative correlation from -0.5 to 0.00 , the finding proved the strong correla- tion between equipment (0.670), hygiene (0.680), places (0.785), streets $(0.737)$, to the environment variable, but one of its indicator toilet (0.455) is characterised with the weak correlation which give the following meaning: toilets in the tourism place Malang need to be improve because its conditions not allowed the ease for tourists, and it is the prerequisite for human life in any place in other to protect our health from diseases. 


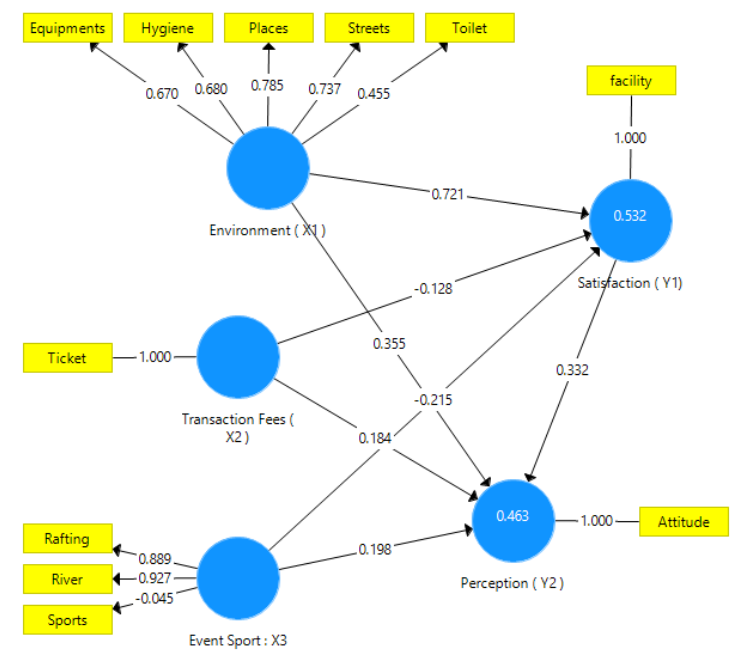

Diagram 2. The Research Structural Equation Modeling Result

Tourist's satisfaction was strongly influenced by the environment current situation with relationship of $r(0.721)$, the simple explanation of the strong relationship between environment and tourist satisfaction was the good management allocated to the previous indicators (equipment hygiene, places, and street). The correlation between transaction fees and tourist 'satisfaction was negative $(-0.128)$, this means that the two variables are characterised with opposite relationship: so in this tourism place the price, entered ticket, ticket for join the sport event, price for food and drinking were expensive the reason why the satisfaction of tourists was decreased. It is up to the manager to balance the facilities in every fielder of his business in other to maintain the customers. However the sport event was very interesting in the size of rafting $(\mathrm{r}=0.889)$, river $(\mathrm{r}=0.927)$, the strong positive correlation was the product from the good management in rafting by the authors of rafting. Nevertheless the negative correlation between different types of sports and sporting event $(r=-$ 0.045 ) evoked a deep need to increase the participation in the different sport domains that means: the more the lack degree of types of sports increases negatively the more flow decreases the participation of the tourists. The lacking of types of sports had indirectly influenced the satisfaction of tourists through the sporting event with $r=-0.215$ : the more lack the types of sports it decreases the tourist 'satisfaction

In general the perception of international student on the sport tourism stills need a kind of improving in other to make sure satisfaction of tourists which will directly influence the loyalty tourist as the outcome showed those relationship: environment-perception ( $\mathrm{r}=0.355)$, satisfaction-perception $(\mathrm{r}=0.332)$, transaction fees- perception $(\mathrm{r}=0.184)$, sport event- perception ( $r=0.198)$, all of the relation of the different paired combination were weak which means in each variable stills some key indicator which need to be improve more than others like: toilet in the environment, increase types of sports in the tourism place, to balance the price of every transaction in the business.

There is linear regression between dependent variable and independent variable

Linear regression is a common Statistical Data Analysis technique. In simple linear regression a single independent variable is used to predict the value of a dependent variable. Linear regression attempts to model the relationship between two variables by fitting a linear equation to observed data. A linear regression line has an equation of the form $\mathrm{Y}=\mathrm{a}+\mathrm{bX}$, where $\mathrm{X}$ is the explanatory variable and $\mathrm{Y}$ is the dependent variable. In this research the explanatory variable are sport event (X3), transaction fees (X2) environment (X1), and the satisfaction (Y1), perception (Y2) dependent variables. With the software SPSS this research hypothesis have been verified:

H0: There are no relationships among variables: environment, Satisfaction, transaction fees, sports event and perception.

Ha: There are significant relationships between variables: environment, Satisfaction, transaction fees, sports event and perception.

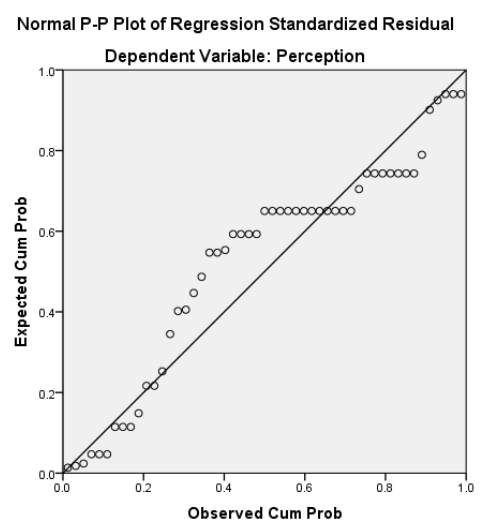

Diagram 3. Regression Standardized Residual environment, Satisfaction, transaction fees, sports event and perception 
The finding of Diagram 3. and Table 3. showed a significant relationship between environment, Satisfaction, transaction fees, sports event and perception with confidence inter- val of $5 \%$. H0 is rejected and received Ha: there is a significant relationship between the variables.

Table 3. Analyse Regression Tariff-Loyalty

\begin{tabular}{llccccc}
\hline & Model & Sum of Squares & df & Mean Square & F & Sig. \\
\hline $1 \quad$ Regression & 3.294 & 4 & .824 & 10.979 & $.000^{\mathrm{b}}$ \\
\cline { 3 - 4 } & Residual & 3.451 & 46 & .075 & & \\
Total & 6.745 & 50 & & \\
\hline
\end{tabular}

a. Dependent Variable: Perception

b. Predictors: (Constant), Satisfaction, Picture ticket, Kind of Sports, Environment

The outcome on the Table 4. is general evaluation which help the manager to know strong or weak points of his business, so in this study pair number: 1,5 , and 6 were significant, but pair number: $2,3,4,7$, and 8 were not significant which means that there is a weak relationship between the combination indicators-variables, and between variable themselves. According to this study it up to the manager of Malang tourism place to improve relation between environment - equipment, environment-toilet, transaction-perception, sport event-perception, and sport even-satisfaction.

In general the study was centred on the search of the correlation which would be between indicators - variable, and the variables between themselves. The regression search allowed to see if the independent variables predict on the values of the dependent variables.

Table 4. Significance testing results of the structural model path coefficients Correlation

\begin{tabular}{lccc}
\hline & N & Correlation & Sig. \\
\hline Pair 1: Facilities \& Satisfaction & 50 & .565 & .000 \\
Pair 2: Toilet \& Environment & 51 & .037 & .798 \\
Pair 3: Equipment \& Environment & 51 & 213 & .133 \\
Pair 4: Kind of Sports \& Satisfaction & 50 & -.083 & .568 \\
Pair 5: Satisfaction \& Perception & 50 & -694 & .000 \\
Pair 6: Condition Street \& Environment & 51 & .278 & .048 \\
Pair 7: Pictures ticket \& Satisfaction & 50 & .024 & .870 \\
Pair 8: Perception \& Kind of Sports & 51 & .042 & .771 \\
\hline
\end{tabular}

\section{Discussion}

The most important contribution of a research is to show how the auctions can be effectively operated by facilitating the service quality of auctioneer and seller. Yen and $\mathrm{Lu}(2008)$ the proposed research model examines perception of tourist on intention regarding trough environment, sport event, transaction fees in all fielder of tourism places, facilities in this place and the satisfaction . Recreational sport is a strong indicator of positive outcomes Lower, Turner, and Petersen (2013), with the above statement, it can be seen the strong positive relationship among indicators and variables. The results of original sample, Structural Equation Modeling (SEM) and linear regression Statistics calculations prove that there is a significant between some dependent variables and independent variables, nevertheless correlation of some indicators with dependent and independent variable, or between variables themselves was not significant like: perception-sport event $(0.771>0.05)$, satisfaction-transaction fees $(0.870>0.05)$, sports event-satisfaction $(0.568>0.05)$, equipment environment $(0.133>0.05)$, toilet-environment $(0.798>0.05)$ in the business it necessary to care of the customer 'need in other to maintain them and to increase or to develop the outcome. The finding above showed point which need to be improved. In today's turbulent economic environment service quality is an invaluable asset that business should manage in order to survive and gain a competitive advantage (Kranias, \& Bourlessa, 2013). All hypotheses were verified and confirmed.

Based on the outcome of the study and discussion that have been put forward, conclusions can be drawn: the perception of international students on the tourism place has demonstrated the kind of guidelines to increase participation in the tourism place, to increase economy field because the tourist pay money for enjoying every activity in the tourism place. In this study the types of sports have to be multiplied, condition of toilet must be improved in the case to allow the good ease to the tourists, transaction fees have to be moderated, in shaping users' continuance intention is very great to maintain the customers. Thus, the suitable environment, multiple kind of sports, tariff moderated become strong management tools that help sports managers to decide how to allocate resources to improve satisfaction, customer loyalty. Appearance of tourism place directly affects customer satisfaction. It can be said that customers will believe in in the Malang place tourism if Malang increase attention to health facilities, including toilet, physical activities: swim pool, football playground, basketball playground, tennis, volleyball, handball, wood ball playground, fitness room ..., procedures, such as, inform the customers appropriately, providing the service to the visitor sincerely (wholeheartedly), and to reduce the tariff. In addition, employees are able to create close family relationships and while communicating using 
empathy, where employees hear more when customers complain, so employees can dig deeper into customer wishes and complaints, which employees can then offer the solution.

\section{Acknowledgements}

We warmly thank to the participants in our research who have given a written consent, but also our deeply feelings gratitude were addressed to the Malang staff who allowed us to do this research in their place as well as the information provided.

\section{Conflict of Interest}

The authors declare that there are no conflicts of interest.

Received: 25 February 2019 | Accepted: 30 April 2019| Published: 01 June 2019

\section{References}

Mhanna, R. (2018). Sport tourism: new challenges in a globalised world. Journal of Sport \& Tourism, 22(4), 349-351. doi:10.1080/14775085.2018 .1532948

Gibson, H.J., Lamont, M., Kennelly, M., \& Buning, R.J. (2018). Introduction to the Special Issue Active Sport Tourism. Journal of Sport \& Tourism, 22(2), 83-91. doi:10.1080/14775085.2018.1466350

Buning, R.J. (2018). Sport tourism development. Journal of Sport \& Tourism, 1(2), 6-14. doi:10.1080/14775085.2018.1548814

Allen, J.T., Drane, D.D., Byon, K.K., \& Mohn, R.S. (2010). Sport as a vehicle for socialization and maintenance of cultural identity: International students attending American universities. Sport Management Review, 13(4), 421-434.

Homafar, F., Honari, H., \& Heidary, A. (2011). The role of sport tourism in employment. income and economic development. Journal of Hospitality Management and Tourism, 2(3), 34-37.

Shin, S., Chiu, W., \& Lee, H.W. (2018). Impact of the Social Benefits of Intramural Sports on Korean Students' Quality of College Life and Loyalty: A Comparison between Lowerclassmen and Upperclassmen. The Asia-Pacific Education Researcher, 22(1), 1-12. doi:10.1007/s40299-018-0425-y

Van Rheenen, D., Cernaianu, S., \& Sobry, C. (2016). Defining sport tourism: a content analysis of an evolving epistemology. Journal of Sport \& Tourism, 21(2), 75-93. doi:10.1080/14775085.2016.1229212
Osman, R.W., Cole, S.T., \& Vessell, C.R. (2006). Examining the role of perceived service quality in predicting user satisfaction and behavioral intentions in a campus recreation setting. Recreational Sports Journal, 30, 20-29.

Higham, J. (1999). Commentary - Sport as an Avenue of Tourism Development: An Analysis of the Positive and Negative Impacts of Sport Tourism. Current Issues in Tourism, 2(1), 82-90. doi:10.1080/13683509908667845

Mousavi Gilani, SR., \& Sajadi, N. (2013), segmentation sport marketing in Iran for foreign tourists and offering tourists the target market model. Sport management, 12(15), 37 -59.

Miller, J.J. (2011). Impact of a university recreation canter on social belonging and student retention. Recreational Sports Journal, 35(2), 117-129.

Athiyaman, A. (1997). Linking student satisfaction and service quality perceptions: The case of university education. European Journal of Marketing, 31(7), 528-540.

Elliott, K.M., \& Healy, M.A. (2001). Key factors influencing student satisfaction related to recruitment and retention. Journal of Marketing for Higher Education, 10(4), 1-11.

Yen, C., \& Lu, H. (2008). Effects of e-service quality on loyalty intention: an empirical study in online auction. Managing Service Quality: An International Journal, 18(2), 127-146. doi:10.1108/09604520810859193

Mahmud, U. (2017).The Effect of Service Quality on Trust and Loyalty for Giant Customers in Malang. Arab J Bus Manage Rev, 7(5), 322 for Giant Customers in Malang.

Kranias, A. \& Bourlessa, M. (2013). Investigating the Relationship Between Service Quality and Loyalty in Greek Banking Sector. Procedia Economics and Finance, 5, 453-458. doi:10.1016/s2212-5671(13)00053-1

Hiba, A., \& Faisal, F. (2018). Factors influencing the internet banking adoption decision in North Cyprus: evidence from the partial least square approach of the structural equation modeling. Financial Innovation, 322-335. doi.org/10.1186/s40854-018-0111-3

Nimon, K.F. (2012). Statistical Assumptions of Substantive Analyses Across the General Linear Model: A Mini-Review. Frontiers in Psychology, 3, 1-5. doi:10.3389/fpsyg.2012.00322

Lower, L.M. Turner, B.A., \& Petersen, J.C (2013). A Comparative Analysis of Perceived Benefits of Participation between Recreational Sport Programs. Recreational Sports Journal, 37(1), 66-83. doi:10.1123/ rsj.37.1.66 